ELORE (ISSN 1456-3010), vol. 19 - 1/2012.

Julkaisija: Suomen Kansantietouden Tutkijain Seura ry.

[http://www.elore.fi/arkisto/1_12/siivonen.pdf]

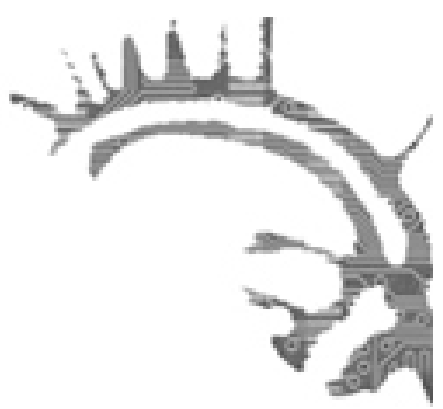

KIRJA-ARVIO

\title{
KULTTUURIPERINTÖ ITSEISARVONA ILMAN VÄLINEARVOA
}

BJÖRKHOLM, JOHANNA 2011: Immateriellt kulturarv som begrepp och process. Folkloristiska perspektiv på kulturarvi Finlands svenskbygder med folkmusik som exempel. Åbo: Åbo Akademis förlag. 355 sivua.

\section{$\underline{\text { Katriina Siivonen }}$}

Musiikki, soittaminen ja yhdessä musisoiminen ovat Johanna Björkholmin väitöskirjan lähtökohta ja ydin. Hän lähtee selvittämään sitä, mitä tapahtuu, kun kansanmusiikki aineettoman kulttuurin elementtinä saa lisäarvoa kulttuuriperinnön statuksesta. Björkholm on rajannut aiheensa alueellisesti ruotsinkieliseen Suomeen ja ajallisesti vuosiin 1848-1968.

Vaikka musiikki on työssä keskiössä, tutkimuksen aineisto koostuu kysymyksenasettelun mukaisesti pitkälti teksteistä, joissa käsitellään kansanmusiikkia ja kulttuuriperintöä. Moninaiset lähteet koostuvat lehtiartikkeleista, esitteistä, tiedotteista ja Internetistä kootusta aineistosta. Lehtiartikkeleita Björkholm on koonnut käymällä systemaattisesti läpi kolmen eri aikakauslehden numeroita, minkä lisäksi hän on käyttänyt kahta suomenruotsalaista lehtileikearkistoa. Björkholm analysoi myös neljän eri arkiston kansanmusiikkiaineistoa. Tieteelliseen kirjallisuuteen perustuva analyysi kulttuuriperinnön käsitteestä nivoutuu osaksi tätä kokonaisuutta. 


\section{KULTTUURIPERINTÖ JA SUOMENRUOTSALAINEN KULTTUURIPERINTÖ}

Björkholmin tutkimus jäsentyy johdannon ja loppupäätelmien lisäksi kahteen pääosioon. Ensimmäisessä niistä hän keskittyy aineettomaan kulttuuriperintöön käsitteenä, toisessa aineettomaan kulttuuriperintöön prosessina. Analyyttisesti koko työ lähteekin liikkeelle kulttuuriperinnön käsitteestä. Sen Björkholm määrittää asiaksi, joka saa lisäarvon kulttuuriperinnöksi nimettynä tai muutoin erityiseen arvoon nostettuna kulttuurin osasena (kulturkomponent) ja joka on siten hänen määrittelyssään jotakin enemmän kuin tällainen kulttuurin osanen.

Ilmiön konstruktiivisuutta korostava näkemys sopii hyvin viimeaikaiseen tieteelliseen keskusteluun kulttuuriperinnön käsitteestä. Tieteellinen nykymäärittely sopii myös hyvin aiempien aikojen aineistojen analyysiin, koska eri aikakausilta löytyy kulttuuripiirteitä, joille on haluttu antaa lisäarvoa niiden erityisen merkityksen vuoksi, minkä Björkholmkin osoittaa analyysissaan. Björkholm nojaa osittain UNESCOn sopimuksin määriteltyyn maailmaperinnön käsitteeseen, mutta katsoo asiaa myös muissa yhteyksissä märïtetyn kulttuuriperinnön kannalta. Selkeää käsitteellistä eroa maailmanperinnön ja kulttuuriperinnön käsitteiden välille hän ei tee eikä siis nosta esille sitä, että kyse näissä on erilaisista juridisista asemista. Maailmanperintöä ovat vain ne ilmiöt, joille on UNESCOn maailmanperintösopimuksiin ja hakuprosesseihin perustuen annettu virallinen asema maailmanperintönä. Kulttuuriperintö on osin kansallisten ja alueellisten viranomaisten kautta saavutettava virallinen status, osin epävirallisesti määrittyvä ilmiö. Näiden selkeä erottelu olisi terävoittänyt analyysia nykyisestä.

Björkholm määrittää kulttuuriperinnön itseisarvoiseksi ilmiöksi, jolla kaikissa yhteyksissä on samankaltainen lisäarvo suhteessa muihin kulttuuri-ilmiöihin. Tämä näkökulma jättää kulttuuriperinnön välineellisen arvon huomiotta. Kuitenkin kulttuuriperinnöllä on aina jokin välineellinen arvo: on jokin tarkoitus sille, miksi se saa lisäarvonsa ja esimerkiksi virallisesti määritetyn statuksensa kulttuuriperintönä. Tämä välineellinen funktio voi vaihdella tilanteesta toiseen.

Björkholmin teoksessa kulttuuriperintö asettuu lähtökohtaisesti rakentamaan suomenruotsalaisuutta jo siten, että työ on rajattu käsittelemään kansanmusiikkia ruotsinkielisen Suomen alueella. Samalla itse tutkimus asettuu samaan positioon, toisin sanottuna tukemaan kulttuuriperinnön suomenruotsalaisuudelle tuottamaa lisäarvoa. Tätä Björkholm ei kuitenkaan tuo esille työn tarkoituksellisena tavoitteena. Sitä, miten musiikki kuvaa nimenomana suomenruotsalaisuutta, ei työssä avata eikä sen rajoja koetella analyysissa. Epäselväksi siten jää, mitkä kansanmusiikin piirteet ovat ominaisia nimenomaan suomenruotsalaisille, mitkä taas ovat tätä ryhmää laajemmin käytössä ihmisten keskuudessa. Samaten sen merkitys jää avoimeksi, miksi tarkasteltavalla musiikilla halutaan rakentaa juuri suomenruotsalaisuutta riippumatta siitä, ovatko kyseisen musiikin elementit olleet käytössä muilla ihmisryhmillä tai eivät.

Ruotsinkielisen Suomen tukeminen näyttäytyy siten itsestäänselvyytenä, jota tutkimuksessa ei kyseenalaisteta. On selvää, että tutkijan arvot vaikuttavat tutkimukseen. Pidän 
myös hyvänä sitä, että tutkijalla on mahdollisuus tutkimuksiensa kautta vaikuttaa ympäröivään maailmaan. Silloin tutkijan arvot tulevat väistämättä mukaan tutkimustoimintaan. Tällöin tutkijan tulee kuitenkin reflektoida tutkimuksessa eksplisiittisesti niitä arvoja, jotka vaikuttavat työn painotuksiin, jotta ne ovat selkeästi lukijoiden arvioitavissa. Siten myös tutkijan itsensä on mahdollista paremmin arvioida omia arvojaan sekä niiden vaikutusta tutkimuksen kokonaisuudessa ja yhteiskunnassa. Tätä Björkholm ei tutkimuksessaan tee.

\section{Aineellista ja aineetonta}

Keskeisenä huomion kohteena tutkimuksessa on aineellisen ja aineettoman kulttuuriperinnön välinen suhde ja keskinäinen asema. Tutkimuksessa aineeton kulttuuriperinne nähdään prosessina ja aineellinen stabiilina olotilana. Kansatieteellisessä aineellista kulttuuria koskevassa tutkimuksessa muutoksen näkeminen osana kulttuuria on kuitenkin ollut oleellinen kulttuurin käsitteen piirre koko tieteenalan historian ajan. Sekä aineellisen että aineettoman kulttuurin piirteistä on varhemmin etsitty stabiileja piirteitä, joiden on katsottu ilmentävän modernia edeltävää ja pitkään sukupolvilta toisille kulkenutta perinnettä. Molempien kulttuurin ulottuvuuksien tutkimuksessa niin folkloristiikassa kuin kansatieteessä on myös siirrytty tarkastelemaan kulttuuria jatkuvasti ajassa elävänä prosessina, jossa sekä aineelliset että aineettomat piirteet koko ajan muokkautuvat uusiin muotoihin.

Nykytutkimuksen näkemys aineellisesta kulttuurista sisältää myös sen, että aineellinen ja aineeton kulttuuri kietoutuvat erottamattomasti toisiinsa. Jokaisella aineellisen kulttuurin ilmentymällä on aineettomia merkityksiä. Esine sinänsä irrotettuna toiminnallisista ja aineettomista ilmiöistä on kulttuurisessa analyysissa vajaa. Samaten aineetonta kulttuuria ei voi ilmentää ilman aineellisia elementtejä. Musiikissakin tarvitaan instrumentteja, minkä Björkholm tuo tutkimuksessaan esille. Myös laulu vaatii aineellisen ihmiskehon tuottamaan ja vastaanottamaan ääntä. Ilman aineellista ulottuvuutta aineettomat kulttuurikomponentit eivät voi välittyä kulttuurina ihmisiltä toisille. Tästä Björkholm keskustelee ansiokkaasti tutkimuksessaan, mutta ei ulota ajatuksiaan aineellisen kulttuurin dynaamisuuteen ja sen aineettomiin ulottuvuuksiin asti.

Kulttuuriperinnön käsitteen esiintymisen ja eriaikaisten merkitysten selvittäminen eri lähteistä on yksi työn ansiokkaista osioista. On kiinnostavaa seurata sitä, miten käsite on ollut käytössä 1800-luvulta lähtien. Kiinnostavaa on myös se, että sen käyttö väheni toisen maailmansodan jälkeen tullakseen uudelleen esille 1990-luvulla. Björkholm tuo esille myös folklorismin käsitteen, joka puolestaan on ollut käytössä sinä aikana, jolloin kulttuuriperintö on käsitteenä ollut vähemmän käytössä tutkimuksissa. Näiden kahden käsitteen suhdetta toisiinsa olisi kiinnostavaa analysoida vielä pitemmälle.

Välineelliseen käyttöön koituvan kulttuuriperinnön yksi ominaisuus on sen kyseenalaistamaton asema kulttuuriperintönä. Björkholmin työssä kansanmusiikki sinänsä asettuu tällaiseen itseisarvoiseen asemaan, koska sen suhdetta välineellisyyteen ei tuoda esille. Björkholm osoittaa musiikin prosessuaalisen muodon aineettoman kulttuuriperinnön olennaiseksi osaksi. Silloin ei ole osoitettavissa sellaisia musiikin piirteitä, joilla olisi ehdoton ja pysyvä asema aineettomana kulttuuriperintönä. Björkholmin analyysin keskiössä 
onkin kiinnostavasti juuri se, miten aineeton kulttuuri voi saada aseman kulttuuriperintönä, vaikka tällaisia yksittäisiä piirteitä ei ole osoitettavissa. Björkholm asettaa aineettoman kulttuuriperinnön statuksen saavuttamisen työssään myös toivottavaksi tavoitteeksi.

Tämä kokonaisuus ei kuitenkaan oleellisesti eroa aineellisen kulttuurin saamasta kulttuuriperinnön asemasta. Samalla tavalla esimerkiksi museoissa käydään jatkuvaa keskustelua siitä, millä esineistöllä tulisi nykyaikana museoiden kokoelmia kartuttaa ja minkä aineistoryhmien dokumentointi kuuluu minkin museon vastuulle tässä työssä. Museot ovat koko ajan dynaamisessa liikkeessä ajan ilmiöiden mukana.

Yksi oleellinen ero tällaisissa prosesseissa kuitenkin on aineellisen ja aineettoman kulttuuriperinnön välillä. Tämän eron Björkholm osoittaa omassa tutkimuksessaan: aineettomien kulttuuripiirteiden mukana ihmiset tulevat tiiviimmin osaksi itse kulttuuriperintöä kuin mitä aineellisen kulttuuriperinnön kohdalla tapahtuu. Museoitavat esineet irrotetaan elävän kulttuurin yhteydestä ja asetetaan museoissa uuteen asemaan suhteessa ihmisten arkeen. Niistä talletetaan tietoa museon kokoelmiin. Sen sijaan aineeton kulttuuri on varsinaisesti olemassa vain hetkellisesti esityksinä, musiikin osalta lauluna ja soittona. Siitä voidaan tallettaa arkistoon äänitteitä tai esimerkiksi sanoja ja nuotinnoksia. Näiden tallentaminen on puolestaan perinnearkistojen perustyötä. Itse elävää esitystä ei kuitenkaan voi konteksteineen sellaisenaan tallentaa. Toisaalta saman voi sanoa myös aineellisesta kulttuurista. Ei ole mahdollista täysin tallentaa esineiden valmistus-, muokkaus- tai käyttöprosesseja konteksteineen.

Se, että esineet ja rakennukset ovat kuitenkin jatkuvasti olemassa fyysisinä kappaleina toisin kuin aineettomat kulttuuripiirteet hetkellisinä ilmentyminä, tuottaa oleellisen eron aineellisen ja aineettoman kulttuuriperinnön välille. Tähän eroon kiteytyy myös syy siihen, miksi aineetonta kulttuuriperintöä ei ole erityisen aktiivisesti lähdetty juridisesti määrittämään länsimaissa. Björkholm esitteleekin kiinnostavasti sitä, miten UNESCOn aineettoman kulttuuriperinnön sopimusta ei ole täällä ratifioitu heti sopimuksen laatimisen jälkeen toisin kuin Aasiassa. On hienoa, että tämän ilmiön esittely on päässyt tutkimuksen tekstiin mukaan Björkholmin teoksessa. Björkholm ei kuitenkaan erittele syvällisemmin niitä syitä, jotka ovat sen taustalla, että länsimaissa UNESCOn sopimusta ei ole ratifioitu.

Nykyisessä globalisaation prosessissa kulttuurin symbolinen arvo esimerkiksi kaupallisessa mutta myös poliittisessa käytössä kasvaa koko ajan. Tästä syystä länsimaissa on syntynyt entistä suurempi kysyntä sille, että aineetonta kulttuuria tulisi määritellä UNESCOn korkealla statuksella aineettomaksi maailmanperinnöksi. Aineettoman maailmanperinnön vahvalle statukselle on entistä enemmän käyttöä sekä eri kansallisuuksien ja alueiden paikallisessa määrittämisessä, globaalissa näkyvyydessä ja sekä näiden alueiden että niiden tuotteiden ja palvelujen maailmanlaajuisessa markkinoinnissa. Kulttuurin käyttöarvoa puolestaan korostetaan esimerkiksi Euroopan unionin kulttuuripolitiikassa sekä eurooppalaisella että alueellisella tasolla. Nämä arvot ovat nyt ajamassa yksilöperustaisten kulttuuristen prosessien vapauden edelle globaalisti. Nämä ovat seikkoja, jotka liittyvät kulttuuriperinnön välineelliseen käyttöön ja joihin Björkholm ei tutkimuksessaan puutu. 
On selvää, että Björkholmin työ olisi laajentunut liikaa, jos analyysi olisi ulotettu kovin pitkälle kulttuuriperinnön välineelliseen käyttöön. Työn suurimmat ansiot ovat siinä, miten kulttuuriperinnön käsitteen esiintymistä, aineellisen ja aineettoman kulttuuriperinnön suhdetta ja musiikkia yhtenä aineettoman kulttuuriperinnön esimerkkinä on analysoitu. Olisin kuitenkin toivonut, että pohdintaan olisi sisältynyt hiukan enemmän tietoisuutta kulttuuriperinnön välineellisestä käytöstä, joka hyvin tiiviisti vaikuttaa kulttuuriperinnön määrittymiseen ja luonteeseen kunakin aikakautena.

Filosofian tohtori Katriina Siivonen on kulttuuriperinnön tutkimuksen, erityisesti soveltavan kulttuurintutkimuksen dosentti Turun yliopistossa ja toimii etnologian tutkimusjohtajana Åbo Akademissa. 